\title{
Mianwali Folklore Notes
}

\section{A. J. O'Brien}

To cite this article: A. J. O'Brien (1911) Mianwali Folklore Notes, Folklore, 22:1, 73-77, DOI: 10.1080/0015587X.1911.9719465

To link to this article: http://dx.doi.org/10.1080/0015587X.1911.9719465

$$
\text { 曲 Published online: } 06 \text { Feb } 2012 .
$$

Submit your article to this journal 중

Q View related articles $\sqsubset$ 
at a gallop and took the child, and went and killed (it), and took some blood in his hand and came and rubbed it on the scholar's eyes, and the eyes opened. They were travelling along. The mother did not know. Then the two Doves came and alighted (in the road) again. One of them said,- "The King's son and priest's son came to search for a bride. God granted them (their quest), and they obtained it. $\Lambda$ snake and the priest's son had a tussle. The snake spat spittle into the boy's eyes, and he became a blind man." Then they flew on again along the road. One of them said,- "Give me the eye that I may see." She said,- "When they took the road, if they had known, they would have returned to the place where the boy was whom they had killed. They would have picked some leaves in the place, and would have touched the boy with them and he would have come to life." The young scholar understood. The King's son did not understand. Then he returned at a gallop to where the boy was. The King's son said, - "Where are you going?" IIe said, - "Wait a minute." He came and broke off a branch at the place, and touched the boy with it, and the boy came to life. Ile took the boy at a gallop, and began galloping and galloping, and he came and gave him to the nurse. Then he passed and overtook the King's son, and said, "Let us go." He said,- " Where did you go just then?" He said,- "I let something fall, and I went back and got it." When they had come to the river at the gate of the town, they let attendants go into the town first. Then he saw the boy on a woman's back. Then he pulled his turban over his mouth, and began laughing. They divided their riches, and remained.

A. J. N. Tremearne.

(To be continused.)

Mlanwal Folklore Notes.

In igot the District of Mianwali was formed out of the two Panjab halves of two older districts, and I had the good fortune to 
be put in charge. It was a lonely District with, as my Assistant Mr. Bolster called it, "three white men in a wilderness of sand." IIe was at the subdivision of Bhakkar, 55 miles off, and the Police Officer lived with me in Mianwali.

Naturally, in a place like this, one gets to notice many things that pass unobserved in a crowded Cantonment full of gaieties or distractions. Among those who became the subject of study in Mlianwali were my chuprassis (doorkeepers), and it happened that all three were characters in their way. The youngest one had been a hawksman before he became an orderiy, and was therefore told off to look after guns and help in all forms of sport. He could never be got to approve of shooting on Fridays, and was much upset if a hare crossed our path early in the morning; and he would not, unless forced, count the bag until all prospect of further sport was ended, as to do so was likely to stop the bag at the amount counted. But these ideas have near parallels in most places. The other chuprassis were better worth folklore study. When I was a bachelor, the principal thing that I noted was that the older man conceived from the first a great reverence for my powers as a magician. The annual rainfall in Mianwali is only rof inches, and in Blsakkar 7, and there were several prolonged droughts during my incumbency, but this had no effect on his belief in me. Rain secmed to fall, either when I was in Mianwali, which was obviously due to my presence there, or it fell in places to which I had gone, and nothing but my arrival had brought it to such spots. So far did my reputation as a rainmaker carry me, that, after I experienced one or two heavy roakings on the little hill to which I resorted for a portion of the hot weather,-and rain that falls in an arid area is rain, and not the drizzle that goes under that title in this country,-I discovered that Tahla Ram would induce me to get out a good distance from home without either waterproof or umbrella when there appeared a chance of a storm rolling up. I challenged him about this, and he pointed out that on certain occasions $I$, the IIead of the District, had got wet, and the whole District had been well wetted with me, and that it was incumbent on me to try and obtain the same effect whenever possible. On another occasion we arrived on the Hill on a Monday about the 20 th of 
June and not a drop of rain fell until July 26 th, though rain was both needed and expected in June. Fortunately for my reputation, an officer from another District had arrived on the Sunday, and all through those long weeks Tahla Ram spent his time in rubbing into the subordinates of the other District, with irritating reiteration, the remark that "some one with inauspicious feet had arrived on the Hill before his Lord."

But I did not understand Tahla Ram fully until I married and my wife attained to the condition which we cloak over, but which the simpler natives, welcoming the thing that must please their master, were delighted to observe,-the condition, as it is termed by them, of "Hope."

I must state that to lonely men in a lonely District shooting is the only thing that preserves life,-the life of the lonely man, not of the birds; and, as the season wanes, and one knows that blank days of unalloyed heat and duststorms are before one until September and the Hill Partridge come again, every possible day becomes precious to one. I was surprised, however, to find that, towards the end of the season, messages to my pet shikarri miscarried, that the call-birds for quail had collected few of their friends near them, and that altogether shooting had failed before the end of the season. It was not till two rock pigeons settled, as pigeons were wont to do, on the roof of my house, that Tahla Ram disclosed his hand. "IVhy kill in these days?" he said, "Life is very precious to you."

$\Lambda$ further manifestation of the same idea occurred a little later. I had taught my wife to shoot, as I had my sister before I married. The discouragement of women shooting is an excellent thing where preserved game is scarce enough to be preserved for man alone, but, in a lonely District where there is nothing to do but shoot, it is well that a woman should take an interest in the only thing that is of interest. My wife showed such prowess on birds of various kinds that, when she took a severe fever in May, Tahla Ram ascribed it to the Evil Eye of one or other of the numerous persons who had applauded her skill.

The other chuprassi was a pudding-headed creature, with, as is often the case with stupid people, many and great redeeming qualities. He thoroughly understood the serious notions of his 
superior, - that nothing must be allowed to upset the possibilities of "Hope." So, when the gardener came to the veranda in my absence with the cry to the Mem-sahib that a particular brute of a parrot was eating the best vegetables and had come back time and again, despite the gardener's shouts, Sultan chuprassi hurried out with the gun he had been ordered to hold and fired at the parrot while his mistress was putting her sun bat on. There are some who, on the instigation of the gunner anxious to practise, would have beaten that chuprassi full sore, but could I do it when I understood the kindly idea underlying the action?

However, from Evil Eye or mosquito-born germs my wife developed a very serious fever, which in the end meant for me and my brother-in-law a twelve-hour walk by her doolie and a thirty-six hour railway journey, and Tahla Ram was with us all the time. Before we determined to move her to Simla I was in a great state of distress, as the fever persisted. I knew by experience how to bang out fever from myself with great doses of quinine abnormally applied, but how to cure a woman "in Hope" was beyond me. Tahla came to me one day and propounded his method of relief. "The Mrem-sahib has been overlooked by evil eyes which were astounded at her shooting; allow me to perambulate seven times round her bed, burning pepper, and all will be well." I would have allowed it, as a good folklorist, but burnt red pepper seemed to have possibilities of annoyance, and so the matter dropped.

In the end, despite the serious troubles beforehand, "Hope" turned into perfect maturity, and a small son was born who from the first, (and, as we say in Mianwali, to avoid the Evil Eye, "till tomorrow"), has been a fine specimen of the race. But Tahla Ram was dissatisfied at the approbation bestowed on him by all alike in the carly days, and we found him strongly discountenancing the practice which brought the infant out into the veranda in the mornings to be observed by servants, orderlies, police constables, and others. Finally, as he found the practice did not cease, he was not going to allow the child to risk the effect of the Evil Eye, and so with much ceremony and prayer he tied a red thread round his little wrist. We let it remain on some hours, and then explained that one tying would have all the effect needed. Tahla 
Ram acquiesced doubtfully. He would have preferred the red thread daily.

But after all it was our European nurse who, impressed by the stories the natives told her about the power of the Holy Saints who are so numerous near the Indus, asked a peculiarly fat one to pray for the child. She gave him a rupee, and was sorry she had, because after blowing on the coin and waving it three times round the head of the infant, above whom he then breathed heavily with a saintly breath, he only prayed that he might become a Commissioner, - a person of importance, but not at the head of the Official Hierarchy. "Pray for him to be a Lieutenant Governor, a Lord-Sahib," she asked. Just then I emerged from the Resthouse, and the fat man was saved any further trouble.

\section{A. J. O'BrIEN.}

\section{Arasentan Folk-Tales (continued).}

\section{Tenthousandfold. 1}

Once upon a time there lived a man and a woman. This man was very pious. Hie goes to church every day. He gives a piastre to the priest each day, and every day the priest says to him,--" Blessed one, may Tenthousandfold give you a thousand in place of one." The man rejoices; he says to himself,- "This is a good thing. I give one; I shall receive a thousand !"

In the course of time he gives all that he has to the priest, and is left penniless. His wife says to him,- "Arise, go to the priest; bring one thousand to give for bread and food, to last us till he pays us the remaining thousands little by little."

The man goes. - "Blessed of the Lord!"

"God bless thee!"

"O priest dear, I gave you so much that you might return thousands and thousands. Now, bring me a thousand to casry home, and I'll come later for the rest."

"Blessed one," says the priest, "you gave to me in order that Tenthousandfold should return you a thousand in place of one."

2 This is the third story in Manama. 